\title{
'Green economy' as a strategy of modernization of older industrial areas in the Urals
}

\author{
I. M. Golova, A. F. Sukhovey $\square$ \\ Institute of Economics, Ural Branch of the Russian Academy of Sciences, Ekaterinburg, Russia; \\ e-mail: alla_suhovey@list.ru
}

\section{ABSTRACT}

This article discusses 'green economy' as a crucial principle of regional socio-economic development at its current stage. In the Russian context, this principle is particularly relevant in the light of the catastrophic increase in pollution of the human environment and habitat. 'Green' economy focuses on modernization of production to ensure its sustainability and restoration of human habitat. The empirical part of the study deals with the social, economic and, above all, environmental problems (resource depletion, pollution, increased health risks) faced by older industrial regions in the Urals (Sverdlovsk, Chelyabinsk and Kurgan regions). These regions are now struggling with the decline of their key industries, such as mining and metallurgy. It is shown that the problems they currently face largely stem from the orientation of the Russian economy towards raw material exports. The article also analyzes the innovation and technological potential of these regions and their priorities of socio-economic development. It is shown that their potential (e.g. human capital) is sufficient to modernize their economies. Some recommendations are formulated for these regions' more efficient transition to the 'green economy'. These include the development of high-tech industries and eco-friendly technologies, introduction of modern environmental standards of economic activity as the basis of modern regional socio-economic systems.
\end{abstract}

\section{Зелёная экономика как стратегия модернизации старых индустриальных районов Урала}

\section{KEYWORDS}

green economy, green growth, sustainable development, environmental modernization, innovation model

\section{ACKNOWLEDGEMENTS}

The research was supported by the Project of Fundamental Studies of the Ural Branch of the Russian Academy of Sciences № 18-6-7-18 'Sustainable Scientific and Technological Development of Regions Based on Green Economy Principles'.

\section{FOR CITATION}

Golova I. M., Sukhovey A. F. (2019) 'Green economy' as a strategy of modernization of older industrial areas in the Urals. R-economy, 5(4), 168-175. doi: 10.15826/ recon.2019.5.4.017

\author{
И. М. Голова, А. Ф. Суховей
}

Институт экономики Уральского отделения Российской академии наук, г. Екатеринбург, Россия; e-mail: alla_suhovey@list.ru

\section{АННОТАЦИЯ}

В этой статье рассматривается «зеленая экономика» как важнейший принцип социально-экономического развития региона на современном этапе. В России этот принцип особенно актуален в свете катастрофического увеличения загрязнения окружающей среды и среды обитания человека. «Зеленая» экономика ориентирована на модернизацию производства с целью обеспечения его устойчивости и восстановления среды обитания человека. Эмпирическая часть исследования посвящена социальным, экономическим и, прежде всего, экологическим проблемам (истощение ресурсов, загрязнение, повышенный риск для здоровья), с которыми сталкиваются пожилые промышленные районы Урала (Свердловская, Челябинская и Курганская области). Эти регионы сейчас борются с упадком их ключевых отраслей, таких как горнодобывающая и металлургическая. Показано, что проблемы, с которыми они сталкиваются в настоящее время, во многом связаны с ориентацией российской экономики на экспорт сырья. В статье также анализируется инновационно-технологический потенциал этих регионов и их приоритеты социально-экономического развития. Показано, что эти регионы имеют потенциал (например, человеческий капитал), достаточный для модернизации их экономики. Сформулированы некоторые рекомендации для более эффективного перехода этих регионов к «зеленой экономике». К ним относятся развитие высокотехнологичных производств и экологически чистых технологий, а также внедрение современных экологических стандартов экономической деятельности.

(๑) I. M. Golova, A. F. Sukhovey, 2019

\section{КЛЮЧЕВЫЕ СЛОВА}

зеленая экономика, зеленый рост, устойчивое развитие, экологическая модернизация, инновационная модель

\section{БЛАГОДАРНОСТИ}

Работа выполнена при поддержке Проекта фундаментальных исследований Уральского отделения Российской академии наук № 18-6-7-18 «Устойчивое научно-техническое развитие регионов на основе принципов зеленой экономики».

\section{ДЛЯ ЦИТИРОВАНИЯ}

Golova I. M., Sukhovey A. F. (2019) 'Green economy' as a strategy of modernization of older industrial areas in the Urals. R-economy, 5(4), 168-175. doi: 10.15826/ recon.2019.5.4.017 


\section{Introduction}

The current social, economic and environmental situation makes it pertinent to adjust and modernize the paradigm of socio-economic development of older industrial areas in the Urals. As local reserves of metal ores are exhausted, the Ural mining and metallurgical industry is losing its competitive edge, which is accompanied by the disappearance of some traditional industries for this region (mechanical engineering, light industry, etc.) and exacerbation of unemployment, especially in mining cities and towns. On the basis of the official statistical data, we have calculated that by 2017 steel production in the Ural Federal District (UrFD) had declined by $22.5 \%$ in comparison with 1990; the production of steel pipes, by $30.5 \%$; the production of metal cutting machines is now only $3.2 \%$ from the level of 1990; tractors, $1.4 \%$; excavators, $0.3 \%$ ). Production of household appliances such as washing machines, refrigerators has been stopped completely. As a result, five urban districts in Sverdlovsk region and seven in Chelyabinsk region, with the population of 284 and 136 thousand people respectively, were included in the national list of mono-profile territories with the most difficult socio-economic situation ${ }^{1}$. The reasons behind this situation are obvious: the lack of proper state regulation when these areas were adapting to the new market environment during the period of reforms, the redistribution of property of former state-owned organizations, and the widening technology gap. It should be noted, however, that in the last thirty-fifty years of the twentieth century, environmental problems were also seriously exacerbated due to intensive exploitation of natural resources, large concentrations of 'dirty' industries and the use of unsustainable technologies. According to the Environmental Performance Index, Russia ranks only 52 nd out of 180 countries (Table 1 ).

The poor environmental performance of Russia can be explained by the long-standing orientation of the country's economy towards raw material exports; high proportion of energy-intensive, environmentally unfriendly industries; significant wear and tear of industrial production facilities; lack of economic incentives for enterprises to develop environmentally friendly technologies; and structural corruption in production monopolies.

${ }^{1}$ Population of municipalities in the Russian Federation. Retrieved from: https://www.gks.ru/folder/11110/document/13282
Table 1

Ranking of countries by the Environmental Performance Index, 2018

\begin{tabular}{|c|c|c|c|c|}
\hline \multirow{2}{*}{$\begin{array}{l}\text { Posi- } \\
\text { tion }\end{array}$} & \multirow[t]{2}{*}{ Countries } & \multirow{2}{*}{$\begin{array}{c}\text { Envi- } \\
\text { ronment } \\
\text { Index }\end{array}$} & \multicolumn{2}{|c|}{ Including indices: } \\
\hline & & & $\begin{array}{c}\text { environmen- } \\
\text { tal health }\end{array}$ & $\begin{array}{c}\text { ecosystem } \\
\text { vitality }\end{array}$ \\
\hline 1 & Switzerland & 87.42 & 93.57 & 83.32 \\
\hline 2 & France & 83.95 & 95.71 & 76.11 \\
\hline 5 & Sweden & 80.51 & 94.41 & 71.24 \\
\hline 6 & UK & 79.89 & 96.03 & 69.13 \\
\hline 10 & Finland & 78.64 & 99.35 & 64.83 \\
\hline 13 & Germany & 78.37 & 88.68 & 71.5 \\
\hline 27 & United States & 71.19 & 93.91 & 56.4 \\
\hline 51 & Venezuela & 63.89 & 75.74 & 55.99 \\
\hline 52 & Russia & 63.79 & 75.48 & 55.99 \\
\hline 60 & South Korea & 62.30 & 73.30 & 54.96 \\
\hline
\end{tabular}

Compiled by the authors by using the data from: Environmental Performance Index. Available at: https://epi.envirocenter.yale.edu/

Older industrial areas of the Ural Federal District (UrFD) include Sverdlovsk region, Chelyabinsk region and a number of municipalities in Kurgan region. These territories have similar natural environments and, even on the national scale, can be classified as struggling and disadvantaged. Regarding emissions of pollutants into the atmosphere from stationary sources, Sverdlovsk region ranks fourth among other Russian regions while Chelyabinsk, seventh. These regions rank among the worst in other indicators such as the volume of contaminated wastewater or waste formation (see Table 2). Given the reduced capacity for self-healing of the natural environments of northern territories and their water scarcity problems, such man-made pressure on water facilities poses a serious danger not only to local biocenoses, but also to communities and individual residents.

Older industrial Ural areas have for many years been suffering from increased health risks: according to the Ministry of Natural Resources of the Russian Federation, $63.4 \%$ of the population of Sverdlovsk region lives in municipal districts where enterprises are major sources of pollution of the natural environment. The most polluted city of the region is Nizhny Tagil. Emissions of harmful substances into the atmosphere by its industrial enterprises now amount to about 200,000 t. The main pollutants are the Nizhny Tagil Metallurgical Plant and Vysokogorsky Ore Mining and Processing Plant, which are responsible for $90 \%$ of emissions. The air in the towns of Kamensk-Uralsky and Krasnoturyinsk is contaminated with fluoride compounds (fluoride hydrogen, solid fluo- 


\section{Table 2}

Anthropogenic impact on the environment in the Urals, 2017

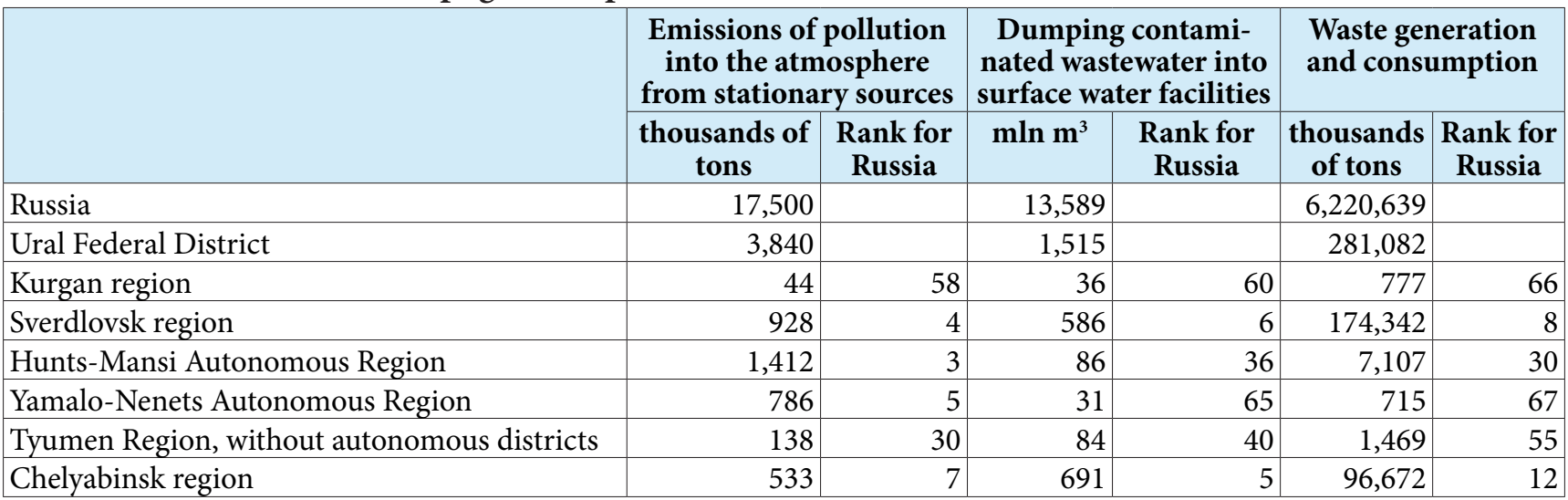

Compiled by the authors by using the data from: Federal Government Statistics Service. Section: Environmental Protection. Available at: https://www.gks.ru/folder/210/document/13209

ride), due to the activity of aluminum plants ${ }^{2}$. In 2017, water samples in Sverdlovsk region, including the largest metropolis Ekaterinburg, showed that in $15 \%$ of cases, water was classified as 'contaminated'; in 79\%, as 'dirty'; and in 6\%, as 'extremely dirty'.

In terms of health risks, Sverdlovsk, Chelyabinsk and Kurgan regions are now classified by the Russian Consumer Watchdog as the most problematic, from the point of view of natural environments. These regions were included in the cluster of regions with a strong impact on public health.

In order to change the situation, serious systemic modernization of economy is necessary. Industrial development, depletion of resources together with unfavorable natural and climatic factors predetermined neo-industrialization as a mandatory condition for older Ural industrial regions to restore their competitiveness, reduce outbound migration and preserve the quality of human potential. At the same time, one of the most important goals of modernization in the Urals should be to address the environmental problems and reduce the risks to public health due to the pollution of the natural environment.

Given the international approaches to longterm sustainable development and the severity of environmental problems in the Urals, it seems that particular attention in the process of its economic modernization should be focused on the transition to the principles of 'green economy'.

2 The current environmental situation and environmental safety issues. Retrieved from: https://geografia-sverd.ucoz. ru/index/ehkologicheskie problemy/0-46

\section{Theoretical framework and international experience}

The concept of green economy is known to have been used for the first time in the work 'Blueprint for a Green Economy' in 1989. Later, the concepts of green industry, green markets, green employment and others started to be used in international documents. The documents adopted at the UN Conference on Sustainable Development, RIO+20, held in Rio de Janeiro in 2012, explicitly stated the need for the world community to transition to a green economy as a new development model ${ }^{3}$.

The term 'green economy' is interpreted differently today. A widespread understanding of green economy proposed in the UN Environment Program - UNEP is that it means ensuring long-term improvement in people's well-being and reducing inequality and allowing future generations to avoid significant risks to the environment and its impoverishment ${ }^{4}$. This understanding of green economy, according to Blanco, E. [1, p. 16], B. N. Porfiryev [2, pp. 33-40], N.V. Pakhomov [3, pp. 88-98], is close to the well-known concept of sustainable development and is an attempt to resuscitate it due to the increasing crisis in the world economy (falling GDP, rising pressure from multinational companies, environmental problems, etc.). However, we find much more persuasive the view that 'green economy' is a new type of economy opposed to the previous man-made type of economic develop-

${ }^{3}$ Rio 20 final document - 'The Future We Want'. Retrieved from: http://grow.clicr.ru/news/81

${ }^{4}$ Assess Europe's environment. European Environment Agency, 2011. Generalized report. Copenhagen. Retrieved from: http://www. eea. europa. eu 
ment, based on the use of artificial means of production, created without taking into account environmental restrictions [4, p. 34; 5, p. 89].

For example, the acid rains resulting from emissions of industrial waste into the atmosphere in the UK were recorded in Norway; Sweden was affected by the Chernobyl disaster; the Great Lakes on the U.S.-Canada border suffer from the negative effects of the runoffs of American businesses. In the 1990s, environmental problems acquired a new, global dimension. The greenhouse effect, which is a consequence of emissions of inert gases into the atmosphere, caused global warming, which led to radical climate changes in almost all regions of the world (snowfalls and hurricanes in the U.S., floods in Germany and other countries Western and Eastern Europe, summer heatwaves, drought and tornadoes in many regions of Russia) [6, p. 39]. OECD experts predict that if modern production and consumption levels continue to persist by 2050 , between 61 and $72 \%$ of the world will lose 61 to $72 \%$ of its flora and fauna by 2050, and the conservation of natural areas will be irreversibly disrupted by 7.5 million square kilometers ${ }^{5}$.

The urgent need to overcome these negative changes, which threaten human survival in the foreseeable future, has led the world community to try to develop a universal integrated strategy for environmental modernization [7, p. 147]. This strategy has been referred to as 'green growth' and focuses on the idea of stimulating economic progress through a shift to sustainable development [8, p. 21]. This approach initially involves concentration on the development options of societies (countries, regions, etc.) on the consideration of the growth constraints imposed by the assimilation capacity of natural environments and the requirements for maintaining an acceptable ecological condition environment and sources of life for future generations ${ }^{6}$.

In response to the need to overcome the negative changes associated with environmental imbalances, the global community has now set out the priorities of green economy aimed at addressing the most acute environmental problems. According to UNEP, these areas include: effective use of natural resources; preservation and increase of natural capital reducing pollution;

${ }^{5}$ Overview of energy technologies. Scenarios and strategies until 2050/ OECD/IEA; WWF Russia. Retrieved from: https://wwf.ru/upload/iblock/164/perspective 20x27 new.pdf 1989. reducing carbon emissions; reventing the loss of ecosystem services and biodiversity; income and employment growth [9, p. 176].

Many countries adopt laws and programs to protect and restore the environment: for instance, Finland currently has 14 national transition programs for green economy; the UK, 9; Germany, 7; and Sweden, 4 [10, p. 37]. In 2000, Australia passed a law to introduce a mandatory renewable energy standard and bring its share of total consumption to $10 \%$ by 2010 . This figure was reached in 2009 and in the same year a new goal was set, obliging the state to increase this share to $20 \%$ by 2020 , as well as the EU average ${ }^{7}$. In the United States, to combat smog, Los Angeles passed a special law requiring every car company that has been selling its cars in California since 2005 to produce at least $10 \%$ of environmentally friendly vehicles with zero emissions of pollutants into the atmosphere from the total number of cars. In France, a scheme to pay bonuses to buyers of cleaner cars is used, which stimulates demand for 'green' cars and contributes to the expansion of their production. In the UK, there are subsidies (2,000-5,000 pounds) for purchase of electric cars [11, pp. 30-31]. Japan is considered to be the most ecologically advanced country: producing about $7 \%$ of global GDP, it emits only $5 \%$ of carbon dioxide and $1 \%$ of sulphur oxides from all global emissions [12, p. 41].

South Korea was the first country to announce the concept of green growth as a national strategy. Sweden plans to phase out oil, coal and gas and switch to renewable energy by 2020. Japan developed the Low Carbon Action Program and set a low standard for carbon emissions as a long-term development goal. In the U.S., the 'green economy' already provides products and services worth of more than 600 billion dollars (4.2\% of GDP) and jobs for 3 million people. The UK (8.8\%) became the world leader in the share of the green sector in GDP.[13]. By 2025, the global market for environmentally friendly equipment is estimated to reach 4.4 trillion euro, which will provide more than $30 \%$ annual average growth and increase the contribution to world GDP to $6-7 \%$. By 2020 , we can expect that the global market for clean technologies will double, the number of people employed in the relevant sectors will increase almost 4 times and the contribution of the green economy to world GDP, by at least 5\% [14].

${ }^{7}$ Renewable Energy (Electricity) Amendment 2009. Retrieved from: http://parlinfo.aph.gov.au/parlinfo/download/ legislation/billslst/ 
The foundation of the 'green' economy is the use of environmentally efficient innovative technologies (energy-efficient and alternative energy technologies, 'green' transport, air and water emissions management, etc) aimed to reduce the human pressure on the environment [15, p. 119].

\section{Methodology and data}

Administrative and legal regulation play a key role in environmental protection and transition of a country (region) to the 'green economy'. Economic measures used to influence the behavior of environmental users can play only an auxiliary corrective role due to the fact that implementation of the principles of the 'green' economy in the public life usually runs counter the interests of those agents that receive immediate benefits and requires a serious change in the underlying motivations of human behavior.

Initially, the damage from the use of natural resources (especially the damage caused by the depletion of non-renewable natural resources) and pollution in human economic activities, given all externalities, including long-term consequences such as the future disposal of utility products after the loss of their consumer properties, always exceeds the benefits. Calculations carried out by E. V. Ryumina have shown that in order to ensure the normative level of waste disposal in production (the maximum permissible concentrations of harmful substances in the environment), Russian energy companies need to increase the share of environmental costs in the cost of energy products 6 times; metallurgy, 4.3 times; fuel, 3.3 times; chemistry and petrochemicals, 2.1 times; and engineering, 2 times. This is unacceptable both in terms of maintaining the competitiveness of the remaining Russian enterprises and in terms of social parameters. Such dramatic increase in payments will lead to immediate bankruptcy of almost all the country's leading industries (energy, chemistry and petrochemicals engineering), except for the fuel industry, whose profitability will also be halved, and steel industry, whose enterprises will be on the verge of break-even [16, pp. 66, 73].

Therefore, in developed countries, the regulation of anthropogenic impact on the environment is usually based on the notion of a socially acceptable level of natural environments and resources, which is consistent with common sense and the idea of a social contract that underpins developed democracies.
However, the socially acceptable level of natural environments for a particular country (civilization) and, therefore, the readiness to switch to 'green' technologies are mostly determined by people's environmental literacy, the level of civic maturity and public engagement and the economic situation. In Russia, due to the peculiarities of its historical development, the system of life values is severely distorted. Moreover, a large part of the population have very low incomes. According to Rosstat, in 2018, $12.9 \%$ of the country's population had an income level below the official subsistence level, which is only $10,287 \mathrm{rub}^{8}$ As a result, the Russian public is largely unaware of the state of the environment, and environmental initiatives, unlike those in developed countries, remain unnoticed by the majority of Russian people. Therefore, industrial enterprises feel free to use cheap, environmentally harmful technologies, thus increasing the risks of wasteful environmental management.

Nevertheless, there are certain advances in the national movement towards the 'green economy'. In 2012, the 'Basics of State Policy on the Environmental Development of Russia for the Period until 2030' were adopted. In this document, the strategic goal of the Russian economy at the present stage is defined as 'solving socio-economic problems and ensuring environmentally oriented economic growth, preservation of the favorable environment ${ }^{9}$. The document also outlines the basic principles and objectives of public environmental development policies, including:

- building an effective environmental and environmental management system;

- improving environmental safety regulations;

- to ensure environmentally oriented economic growth and the introduction of environmentally efficient innovative technologies;

- preventing and reducing the current negative impact on the environment;

- restoration of disturbed natural systems, etc. ${ }^{10}$

A positive shift in the public management of environmental pollution is Russia's transition from emissions control (resets) to establishing allowable emissions (to manage the processes of en-

${ }^{8}$ Federal State Statistics Service. Official website. Retrieved from: https://www.gks.ru/folder/13397

9 The Basics of the State Policy in the Field of Environmental Development of Russia for the Period until 2030. Retrieved from: http://kremlin.ru/acts/15177

${ }_{10}$ The Basics of the State Policy in the Field of Environmental Development of Russia for the Period until 2030. Retrieved from: http://kremlin.ru/acts/15177 
vironmental and technological modernization of production technologies used by business entities through the use of the best available technologies (BAT) mechanism). The EU model for controlling industrial emissions was taken as the basis ${ }^{11}$. In 2014, the relevant amendments were made to the federal law on protection of the natural environment ${ }^{12}$. It should be noted that only objects of the first out of four possible categories fall under the regulation of using the BAT mechanism: those that have a significant negative impact on the environment (Article 4.2).

The best available technologies, however, are not completely the same as 'green' technologies. Article 1 of the Russian Environmental Protection Act interprets the best available technology as a 'technology of production (goods), work, service delivery, determined on the basis of modern advances in science and technology and best combination of criteria for achieving environmental goals, provided it is technically possible to be applied $^{\prime 13}$. However, this interpretation is very vague and leaves much room for manoeuvre. Due to the absence of proper public control and pressure from monopolistic enterprises, there is a risk that this mechanism will be used not only in the interests of conservation, but also to reduce the responsibility of business owners for pollution environment. The definition of the best available technology in the EU documents is more precise: in accordance with the Directives, this term refers to the 'most effective and advanced stage of development of activities and methods of their implementation, which demonstrates the practical suitability of certain technologies for compliance emission thresholds and other permit conditions designed to prevent or, if not feasible, reduce emissions and impact on the environment as a whole ${ }^{14}$.

The passport of the federal project 'Best Available Technologies' (included in the national

${ }^{11}$ Directive 2010/75/EU of the European Parliament and of the Council of 24 November 2010 on industrial emissions (integrated pollution prevention and control). Retrieved from: https://eur-lex.europa.eu/legal-content/EN/TXT/?uri=celex:32010L0075

${ }^{12}$ Federal Law on Environmental Protection of 10.01.2002 N 7-Fz (ed. 27.12.2018). Retrieved from: http://www.consultant.ru/document/cons doc LAW 34823/

${ }^{13}$ Federal Law on Environmental Protection of 10.01.2002 N 7-Fz (ed. 27.12.2018). Retrieved from: http://www.consultant.ru/document/cons doc LAW 34823/

${ }^{14}$ Directive 2010/75/EU of the European Parliament and of the Council of 24 November 2010 on industrial emissions (integrated pollution prevention and control). Retrieved from: https://eur-lex.europa.eu/legal-content/EN/TXT/?uri=celex:32010L0075 project 'Ecology') specifies that in 2019, the first 15 comprehensive environmental permits (CER) will be issued, and by 2022 it is planned that such permits will be granted to 300 enterprises which are the largest polluters of the natural environment in Russia. It is too early to say how this mechanism will work, but the fact that the guidelines concerning the best available technologies were prepared without involving public discussion, in the traditional 'closed-door' way, can be a cause for alarm both among the owners of businesses and people living in their immediate vicinity.

\section{Results}

It should be emphasized that older industrial Ural regions hold a considerable potential for $R \& D$ development. Together with other factors, such as access to highly qualified engineering staff and established traditions of industrial production, this may well provide a good foundation for the development 'green' economy, which is one of the most important components of modernization.

As our calculations show (see Table 3), Sverdlovsk region currently occupies the 9th place in the Integral Index of Innovative Opportunities. Chelyabinsk ranks $16^{\text {th }}$ among other Russian regions. Both regions have the potential to become federal innovation centers focused on technological support and modernization of steel and high-tech industries. These areas also have good prospects for the development of innovative entrepreneurship aimed at improving technological processes of exploration and mining.

For more detailed description of the methodology for assessing the innovative potential of regions see [17]. In our calculations, we took into account such factors as scientific and innovative potential of regions; the potential for innovation demonstrated by their socio-economic environment; and the structure of production.

In order to launch the transition of the older industrial regions to 'green economy' principles, it is necessary:

- to limit monopolies and ensure fair competition;

- to stimulate the development of the middle class and reduce poverty;

- to create adequate financial institutions with the participation of public funds to stimulate the development of modern high-tech industries and implementation of 'green' technologies;

- to provide priority support for national science, education and innovation; 
Comparative assessment of conditions for development of innovation in the Urals, 2017

Table 3

Position in the national ranking

\begin{tabular}{|c|c|c|c|c|c|c|}
\hline \multirow[t]{2}{*}{ Ural regions } & \multirow{2}{*}{$\begin{array}{l}\text { Oppor-tunities } \\
\text { for innovative } \\
\text { development }\end{array}$} & \multicolumn{2}{|c|}{ Including: } & \multicolumn{3}{|c|}{$\begin{array}{c}\text { Feasibility of developing innovation } \\
\text { based on: }\end{array}$} \\
\hline & & $\begin{array}{l}\text { R\&D po- } \\
\text { tential }\end{array}$ & innovation & high-tech sector & metal-lurgy & mining \\
\hline Kurgan region & 53 & 57 & 55 & 40 & 37 & 66 \\
\hline Sverdlovsk region & 9 & 9 & 15 & 7 & 1 & 17 \\
\hline Tyumen Region & 33 & 48 & 14 & 43 & 29 & 1 \\
\hline $\begin{array}{l}\text { including } \\
\text { Hunty-Mansi Autonomous Region }\end{array}$ & 52 & 79 & 16 & 64 & 63 & 2 \\
\hline $\begin{array}{l}\text { Yamalo-Nenets } \\
\text { Autonomous Region }\end{array}$ & 65 & 82 & 51 & 80 & 78 & 3 \\
\hline Chelyabinsk region & 16 & 17 & 29 & 11 & 2 & 21 \\
\hline
\end{tabular}

- to apply modern environmental standards of waste management, waste disposal and so on;

- to provide state support for modernization of life support systems of settlements based on the 'green' economy principles;

- to develop environmental education and education; zations

- to incentivize public environmental organi-

\section{Conclusion}

Transfer to the 'green' model of economy is a natural stage in the evolution of modern socio-economic systems in Russia and other countries. The need for such transfer becomes particularly urgent in the face of the dangers of global climate change, use of environmentally harmful technologies and so on. This problem is relevant for Russia and for its older industrial regions in particular.

The Ural Federal District is known as the primary location of the country's industrial complex- es. It is obvious that these complexes are now in need of some serious modernization, as they are still using obsolete and environmentally unsafe technologies of the third and fourth technological ways of production. It is, therefore, vital that these complexes should embark on innovation programs to enhance their competitiveness and improve the quality of life in the surrounding areas.

The transition of these Ural regions' economies to the 'green' model requires serious mobilization of their management and financial resources. The use of these regions' innovation and technological potential should play an important role in this process. Enhancing the sustainability of their economies will help these regions to tackle such problems as pollution, especially those types of pollution that accelerate climate change, prevalence of energy-intensive industries, loss of biodiversity, depletion of natural resources, increased health risks and poor quality of life, unemployment and low income among the population.

\section{References}

1. Blanco, E., \& Razzaque, J. (2012). Natural Resources and the Green Economy: Redefining the Challenges for People. Leiden-Boston: Martinus Nijhoff Publishers.

2. Porfiryev, B. N. Prospects of a 'green' scenario of development. Retrieved from: http://ecpol. ru/index.php/macroeconomics/2012-04-05-13-39-10/467-perspektivy-zelenogo-stsenariya-razvitiya (In Russ).

3. Pakhomova, N. V., Richter, K. K., et al. (2013). Sustainable Development Strategy and Transition to a Green Economy: Updating Priorities and Mechanisms. Vestnik S-PbGU = St. Petersburg State University Herald, 5(4), 35-54. (In Russ).

4. Yashalova, N. N. (2013). Green Economy: Issues of Theory and Direction development. Natsionalnye interesy: prioritety i bezopasnost $=$ National interests: priorities and security, 11, 33-40. (In Russ).

5. Lukin, M. V., \& Samokhin, I. V. (2016). 'Green economy' as a global trend and prospects for its application in Russia. Regionalnye aspekty upravlenija, jekonomiki i prava Severo-zapadnogo federal'nogo okruga Rossii = Regional aspects of governance, economics and law of the North-West Federal District of Russia, 1, 88-98. (In Russ). 
6. Danilenko, L. N. (2013). Environmental Policy in Russia: Green Economy against rent and raw materials. Ugrozy i bezopasnost = Threats and Security, 12, 38-46. (In Russ).

7. Fischer, C., \& Newell, R. G. (2008) Environmental and Technology Policies for Climate Mitigation. Journal of Environmental Economics and Management. 55(2) 142-162.

8. Niemeijer, D., \& Groot de, R. S. (2008). Conceptual Framework for Selecting Environmental Indicator Sets. Ecological Indicators. 8(1), 14-25.

9. Kennet, M., \& Heinemann, V. (2006). Green Economics: Setting the Scene. Aims, Context, and Philosophical Underpinning of the Distinctive New Solutions Offered by Green Economics. International Journal Green Economics. 1(1/2), 68-102.

10. Cousina, L. V. (2015). 'Green Economy' as an alternative to the existing market economy. Lesnoj vestnik = Forest Gazette, 4, 37-41. (In Russ).

11. Piskulova, N. (2015). Development of the world economy: environmental vector. Mirovaja jekonomika i mezhdunarodnye otnoshenija = World economy and international relations, 12, 30-38. (In Russ).

12. Danilenko, L. N. (2013). Environmental Policy in Russia: Green Economy against rent and raw materials. Threats and Security, 12, 39-45. (In Russ).

13. Ghisellini, P., Cialani, C., \& Ulgiati, S. (2016) A review on circular economy: The expected transition to a balanced interplay of environmental and economic systems. Journal of Cleaner Production. 114, 11-32. DOI: 10.1016/j.jclepro.2015.09.007

14. Porfiryev, B. N. ‘Green' economy: realities, prospects and limits of growth. In: Fond Karnegi za mezhdunarodnyj mir = Carnegie Endowment for International Peace. Retrieved from: http://carnegieendowment.org/files/WP_Porfiriev_web.pdf (In Russ).

15. Horbach, J., Rammer, C., \& Rennings, K. (2012) Determinants of eco-innovations by type of environmental impact. The role of regulatory push/pull, technology push and market pull. Ecological Economics, 78, 112-122. DOI: 10.1016/j.ecolecon.2012.04.005

16. Ryumina, E. V. (2009) Why enterprises do not want and cannot protect the environment: quantitative analysis. Ekonomicheskaja nauka sovremennoj Rossii = Economic science of modern Russia, 4, 66-74. (In Russ).

17. Sukhovey, A. F., \& Golova, I. M. (2019). Innovative component of socio-economic development. Yekaterinburg: IE UrD RAS. (In Russ).

\section{Information about the authors}

Irina Golova - Doctor of Economics, Head of the Sector of Social Innovation, senior researcher, Institute of Economics of the Ural Branch of the Russian Academy of Sciences (Ekaterinburg, Russia, Moskovskaya str., 29); e-mail: irina_golova@mail.ru.

Alla Sukhovey - Doctor of Philosophy, Professor, Chief Researcher at the Sector of Social Innovation, Institute of Economics of the Ural Branch of Russian Academy of Sciences (Ekaterinburg, Russia, Moskovskaya str., 29); e-mail: alla_suhovey@list.ru.

ARTICLE INFO: received June 27, 2019; accepted September 26, 2019

\section{Информация об авторах}

Голова Ирина Марковна - доктор экономических наук, зав. сектором социальных инноваций ведущий научный сотрудник, Институт экономики Уральского отделения Российской академии наук (620014, Россия, г. Екатеринбург, ул. Московская, 29); e-mail: irina_golova@mail.ru

Суховей Алла Филипповна - доктор философских наук, профессор, ведущий научный сотрудник сектора социальных инноваций, Институт экономики Уральского отделения Российской академии наук (620014, Россия, г. Екатеринбург, ул. Московская, 29); e-mail: alla_ suhovey@list.ru.

ИНФОРМАЦИЯ О СТАТЬЕ: дата поступления 27 июня 2019 г.; дата принятия к печати 26 сентября 2019 г.

This work is licensed under a Creative Commons Attribution 4.0 International License

Эта работа лицензируется в соответствии с Creative Commons Attribution 4.0

International License 